\title{
GAMBARAN HISTOPATOLOGI TUMOR KELENJAR LIUR DI MANADO PERIODE JULI 2010 - JULI 2013
}

\author{
${ }^{1}$ Marcella P.J. Merung \\ ${ }^{2}$ Nico A. Lumintang \\ ${ }^{2}$ Harsali F. Lampus \\ ${ }^{1}$ Kandidat Skripsi Fakultas Kedokteran Universitas Sam Ratulangi Manado \\ ${ }^{2}$ Bagian Bedah RSUP Prof. Dr. R. D. Kandou Manado \\ Email: marcellamerung@yahoo.com
}

\begin{abstract}
Salivary glands tumor is relatively rare. In Indonesia, there's still no complete data about the estimated incidence of salivary glands tumor. Objective:To determine the histopathology of the salivary gland tumor in Manado from July 2010 to July 2013. Methode: This was a descriptive retrospective study. Result: There were 70 patients had salivary gland tumorswith52.9\% femaleand $47.1 \%$ male). By age groups found that $\leq 16$ age group for 1,4\%, 17 30 for $28.6 \%$, 31 - 40 for18.\%), 41 - 50 for $21.4 \%, 51-60$ for $14.3 \%, 61-70$ for8.6\%, $\geq 71$ for 7.1\%. By classification histopathology, Pleiomorphic adenoma for $57.2 \%$, Whartin's tumor for 11.4\%, Oncocytoma, Mucoepidermoid carcinoma, and Adenocarcinoma each for 5.7\%, Adenoid cystic carcinoma for 4.3\%,Cystadenoma for 3.0\%, Myoepithelioma, Basal cell adenoma, Canalicular adenoma, Cystadenocarcinoma,and Large cell lymphoma malignant each for $1.4 \%$. By the location, parotis gland for $47.1 \%$, submandibula gland for $27.1 \%$, minor salivary gland for $12.9 \%$ and the other location for $12.9 \%$. Conclusion: Female is more than male, the highest incidence is in the group 17-30 years old, the most common benign tumors is pleomorphic adenoma while the most common type of malignant tumors is mucoepidermoid carcinoma and adenocarcinoma. The most frequent tumor's location is parotid gland.
\end{abstract}

Keywords: Salivary glands tumor, histopathology.

Abstrak: Tumor kelenjar liur merupakan tumor yang jarang ditemukan. Indonesia masih belum ada data lengkap mengenai insiden tumor kelenjar liur.Tujuan: Untuk mengetahui gambaran histopatologi tumor kelenjar liur di Manado periode Juli 2010 - Juli 2013. Metode:Penelitian ini bersifat deskriptif retrospektif. Hasil: Dari 70 penderita tumor kelenjar liurditemukan perempuan $52,9 \%$ dan laki-laki 47,1\%. Kelompok usia $\leq 16$ tahun sebanyak 1,4\%, 17 - 30 tahun sebanyak 28,6\%,31 - 40 tahun sebanyak 18,6\%, 41 - 50 tahun sebanyak 21,4\%, 51 - 60 tahun sebanyak 14,3\%, 61 - 70 tahun sebanyak 8,6\%, $\geq 71$ tahun sebanyak 7,1\%. Berdasarkan klasifikasi histopatologi jenis Pleimorphic adenoma sebanyak 57,2\%, Whartin's tumor sebanyak $11,4 \%$, Oncocytoma,Mucoepidermoid carcinoma, dan Adenocarcinoma masing-masing sebanyak 5,7\%,Adenoid cystic carcinoma sebanyak 4,3\%, Cystadenoma sebanyak 3,0\%, Myoepithelioma,Basal cell adenoma,Canalicular adenoma, Cystadenocarcinoma,dan Large cell lymphoma malignant masing-masing sebanyak $1,4 \%$. Berdasarkan lokasi tumor, kelenjar parotis sebanyak $47,1 \%$, kelenjar submandibula sebanyak $27,1 \%$, kelenjar liur minor sebanyak $12,9 \%$ dan lokasi yang tidak jelas sebanyak $12,9 \%$. Kesimpulan:Penderita perempuan lebih banyak dari lakilaki, insiden tertinggi pada kelompok usia17 - 30 tahun, tumor jinak paling banyak ditemukan adalah pleomorphic adenoma sedangkan tipe ganas adalah mucoepidermoid carcinoma dan adenocarcinoma. Lokasi tumor tersering adalah kelenjar parotis.

Kata Kunci: Tumor kelenjar liur, histopatologi. 
Tumor pada kelenjar liur mewakili 36\% dari seluruh tumor kepala-leher.Dimana dari seluruh insiden tumor kelenjar liur, diperkirakan $80 \%$ berasal dari kelenjar parotis, $10-15 \%$ dari kelenjar submandibula, sekitar 5-8\% dari kelenjar minor, dan $<1 \%$ berasal dari kelenjar sublingual.Klasifikasi histopatologi tumor kelenjar liur dari WHO memiliki 42 nama jenis tumor dengan tumor kelenjar liur yang paling umum adalah pleiomorphic adenoma yang merupakan tumor jinak dan menempati sekitar 75-80\% dari tumor kelenjar parotis dan jenis keganasan tersering adalah mucoepidermoid carcinoma yang menempati $35 \%$ dari seluruh keganasan kelenjar liur. ${ }^{1-5}$

Insiden tumor atau kanker kelenjar liur meningkat terus sesuai dengan peningkatan usia dimana kasus keganasan sering ditemukan pada dekade ke 5 dan ke 6 . Ratarata usia pasien dengan keganasan adalah 55 tahun, dan untuk tumor jinak sekitar 40 tahun. Insiden keganasan pada penderita $<16$ tahun adalah kurang dari 2\%. Jika dikorelasikan dengan jenis kelamin, tidak ada predileksi seksual kecuali pada Warthin's tumor yang dijumpai 5 kali lebih banyak pada laki. 2,6,7

Di Indonesia pada periode 1 Januari 2001 - 31 Desember 2005, telah dilakukan penelitian insiden kanker kepala leher di Laboratorium Patologi Anatomi RS Dr. Kariadi Semarang dimana terdapat 7 kasus kanker kelenjar liur atau sebesar 2\% dari 448 kasus kanker kepala-leher. ${ }^{8}$ Badan Registrasi Kanker Indonesia mencatat ada 120 kasus tumor kelenjar liur pada tahun 2005 dari 13 pusat di Sumatra, Jawa, Bali, dan Kalimantan. ${ }^{9}$ Badan Registrasi Kanker Indonesia juga melaporkan sepanjang tahun
2003 - 2007, di RS Kanker Dharmais, ada total 82 kasus kanker kelenjar liur dengan jenis kanker terbanyak adalah mucoepidermoid carsinoma sebanyak 16 kasus. ${ }^{10}$ Pada penelitian di Departemen Patologi Anatomi FKUI/RSCM dari tahun 2005-2009 ditemukan 65 kasus neoplastik atau tumor kelenjar liur. ${ }^{9}$ Indonesia masih belum ada data lengkap tentang perkiraan insiden tumor kelenjar liur baik jinak maupun ganas, jenis kelamin maupun usia tersering mengidap tumor kelenjar liur. ${ }^{2}$

\section{METODE PENELITIAN}

Penelitian ini bersifat deskriptif retrospektif.Data diambil dari arsip datadi Bagian Patologi Anatomi Fakultas Kedokteran Unsrat dan Laboratorium Patologi Anatomi Swasta di Manadoperiode Juli 2010-Juli 2013. Subjek penelitian yaitu seluruh data penderita tumor kelenjar liur yang ada di Bagian Patologi Anatomi Fakultas Kedokteran Unsrat dan Laboratorium Patologi Anatomi Swasta di Manado pada periode Juli 2010 sampai Juli 2013. Variabel penelitian meliputi jenis kelamin, usia, dan klasifikasi histopatologi.

\section{HASIL PENELITIAN}

Dari hasil penelitian yang dilakukan di Bagian Patologi Anatomi Fakultas Kedokteran Unsrat dan Laboratorium Patologi Anatomi Swasta di Manado periode Juli 2010 - Juli 2013, didapatkan 70 data pasien yang menderita tumor kelenjar liur dengan distribusi per 6 bulan dan 7 bulan

(Tabel

$1)$.

Tabel 1.Jumlah penderita tumor kelenjar liur

\begin{tabular}{ccc}
\hline Periode & Jumlah penderita & Persentase \\
\hline Juli 2010 - Desember 2010 & 6 & $8,6 \%$ \\
Januari 2011 - Juni 2011 & 11 & $15,7 \%$ \\
Juli 2011 - Desember 2011 & 12 & $17,1 \%$ \\
Januari 2012 - Juni 2012 & 17 & $24,3 \%$ \\
Juli 2012 - Desember 2012 & 7 & $10,0 \%$ \\
Januari 2013 - Juli 2013 & 17 & $24,3 \%$ \\
\hline Total & $\mathbf{7 0}$ & $\mathbf{1 0 0 , 0 \%}$ \\
\hline
\end{tabular}


Tabel 2. Distribusi berdasarkan jenis kelamin penderita tumor kelenjar liur

\begin{tabular}{ccc}
\hline Jenis Kelamin & Jumlah penderita & Persentase \\
\hline Laki-laki & 33 & $47,1 \%$ \\
Perempuan & 37 & $52,9 \%$ \\
\hline Total & $\mathbf{7 0}$ & $\mathbf{1 0 0 , 0 \%}$ \\
\hline
\end{tabular}

Tabel 3. Distribusi berdasarkan kelompok usia dan sifat tumor dari penderita tumor kelenjar liur

\begin{tabular}{ccccc}
\hline \multicolumn{5}{c}{ Sifat Tumor } \\
Usia & Jinak & Ganas & Jumlah penderita & Persentase \\
\hline$\leq 16$ & $1(100 \%)$ & - & 1 & $1,4 \%$ \\
$17-30$ & $18(90 \%)$ & $2(10 \%)$ & 20 & $28,6 \%$ \\
$31-40$ & $12(92,3 \%)$ & $1(7,7 \%)$ & 13 & $18,6 \%$ \\
$41-50$ & $13(86,7 \%)$ & $2(13,3 \%)$ & 15 & $21,4 \%$ \\
$51-60$ & $7(70 \%)$ & $3(30 \%)$ & 10 & $14,3 \%$ \\
$61-70$ & $5(83,3 \%)$ & $1(16,7 \%)$ & 6 & $8,6 \%$ \\
$\geq 71$ & $1(20 \%)$ & $4(80 \%)$ & 5 & $7,1 \%$ \\
\hline Total & $\mathbf{5 7}$ & $\mathbf{1 3}$ & $\mathbf{7 0}$ & $\mathbf{1 0 0 , 0} \%$ \\
\hline
\end{tabular}

Distribusi berdasarkan jenis kelamin, penderita tumor kelenjar liur ditemukan yang berjenis kelamin perempuan lebih banyak daripada laki-laki yaitu sebanyak 37 pasien (52,9\%). Sementara yang berjenis kelamin laki-laki berjumlah 33 pasien (47,1\%) (Tabel 2).

Distribusi berdasarkan kelompok usia, penderita yang didiagnosis tumor kelenjar liur paling banyak ditemukan pada kelompok usia 17 - 30 tahun, yaitu 20 penderita (28,6\%). Berdasarkan sifat tumor yaitu jinak dan ganas dihubungkan dengan kelompok usia tidak ditemukan kesimpulan semakin tinggi usia, insiden keganasan semakin meningkat (Tabel 3).

Berdasarkan klasifikasi histopatologi, terdapat 57 penderita (81,4\%) mengidap tumor jinak dengan jenisPleimorphic adenoma mendominasi dengan 40 penderita (57,2\%) dan di kategori keganasan jenis mucoepidermoid carcinoma dan adenocarcinoma yang terbanyak dengan masing-masing 4 penderita yaitu sebesar 30,8\% dari seluruh keganasan. Lokasi asal tumor tersering adalah kelenjar parotis (47,1\%), namun untuk lokasi tersering keganasan adalah kelenjar submandibula (Tabel 4). 
Tabel 4. Distribusi berdasarkan klasifikasi histopatologi dan lokasi tumor kelenjar liur

\begin{tabular}{|c|c|c|c|c|c|}
\hline $\begin{array}{c}\text { Klasifikasi } \\
\text { Histopatologi }\end{array}$ & Parotis & $\begin{array}{c}\text { Sub } \\
\text { mandibula }\end{array}$ & $\begin{array}{c}\text { Kelenjar liur } \\
\text { minor }\end{array}$ & Lain-lain & $\begin{array}{c}\text { Jumlah } \\
\text { penderita }\end{array}$ \\
\hline Tumor Jinak & & & & & $57(81,4 \%)$ \\
\hline Pleimorphic adenoma & $21(63,6 \%)$ & $11(57,8 \%)$ & $4(44,5 \%)$ & $4(44,5 \%)$ & $40(57,2 \%)$ \\
\hline Whartin's tumor & $5(15,3 \%)$ & - & - & $3(33,3 \%)$ & $8(11,4 \%)$ \\
\hline Myoepithelioma & - & $1(5,3 \%)$ & - & - & $1(1,4 \%)$ \\
\hline Basal cell adenoma & $1(3,0 \%)$ & - & - & - & $1(1,4 \%)$ \\
\hline Oncocytoma & $4(12,1 \%)$ & - & - & - & $4(5,7 \%)$ \\
\hline Cystadenoma & $1(3,0 \%)$ & $1(5,3 \%)$ & - & - & $2(3,0 \%)$ \\
\hline Canalicular adenoma & $1(3,0 \%)$ & - & - & - & $1(1,4 \%)$ \\
\hline Tumor Ganas & & & & & $13(18,6 \%)$ \\
\hline $\begin{array}{r}\text { Mucoepidermoid } \\
\text { carcinoma }\end{array}$ & - & $3(15,7 \%)$ & $1(11,1 \%)$ & - & $4(5,7 \%)$ \\
\hline $\begin{array}{r}\text { Adenoid cystic } \\
\text { carcinoma }\end{array}$ & - & $1(5,3 \%)$ & $2(22,2 \%)$ & - & $3(4,3 \%)$ \\
\hline Adenocarcinoma & & $1(5,3 \%)$ & $1(11,1 \%)$ & $2(22,2 \%)$ & $4(5,7 \%)$ \\
\hline Cystadenocarcinoma & - & - & $1(11,1 \%)$ & - & $1(1,4 \%)$ \\
\hline $\begin{array}{r}\text { Large cell lymphoma } \\
\text { malignant }\end{array}$ & - & $1(5,3 \%)$ & - & - & $1(1,4 \%)$ \\
\hline Total & $33(47,1 \%)$ & $19(27,1 \%)$ & $9(12,9 \%)$ & $9(12,9 \%)$ & $70(100 \%)$ \\
\hline
\end{tabular}

\section{DISKUSI}

Dari penelitian retrospektif yang telah dilakukan di Bagian Patologi Anatomi Fakultas Kedokteran Unsrat dan Laboratorium Patologi Anatomi Swasta di Manado selama periode Juli 2010 - Juli 2013 ditemukan sebanyak 70 penderita tumor kelenjar liur. Hal serupa ditemukan pada penelitian dari Lisnawati et al. ${ }^{9}$ yang melakukan penelitian dengan melihat arsip pada Departemen Patologi Anatomik FKUI/RSCM periode 2005 - 2009 dan menemukan 65 kasus tumor kelenjar liur.Tidak bisa disimpulkan bahwa insiden tumor kelenjar liur ini meningkat setiap tahunnya karena masih kurangnya data hasil penelitian terhadap insiden tumor kelenjar liur di Indonesia.

Berdasarkan jenis kelamin, jumlah penderita perempuan lebih banyak daripada penderita laki-laki. Dimana jumlah penderita tumor kelenjar liur berjenis kelamin perempuan sebanyak 37 penderita (52,9\%) dan sisanya 33 penderita $(47,1 \%)$ berjenis kelamin laki-laki. Selisih jumlah penderita perempuan dan penderita laki-laki tidak terlihat perbedaaan yang signifikan sehingga selaras dengan yang dilaporkan Ito FA et al. ${ }^{11}$ pada tahun 2005 bahwa tumor kelenjar liur sedikit didominasi oleh perempuan dan Vargas PA et al. ${ }^{12}$ yang menemukan 124 penderita tumor kelenjar liur dengan 74 penderitanya (60\%) adalah perempuan.

Tumor kelenjar liur paling banyak terjadi pada pasien dengan kelompok usia produktif yaitu 17 - 30 tahun dengan total sebanyak 20 penderita (28,6\%), disusul kelompok usia 41 - 50 tahun sebanyak 15 penderita (21,4\%). Berbeda dengan apa yang dilaporkan Pinkston JA et al. ${ }^{13}$ bahwa insiden tumor kelenjar liur terus meningkat sesuai usia dan puncak meningkatnya insiden pada rentang usia 65 - 74 tahun kemudian usia lebih dari 75 tahun insiden menurun. Kontradiktif juga dengan yang Ito FA et al. ${ }^{11}$ laporkan bahwa insiden tumor kelenjar liur tertinggi pada rentang usia 40 50 tahun. Perbedaan hasil ini disebabkan sampel pada penelitian ini masih kurang mewakili populasi Manado jika 
dibandingkan dengan penelitian-penelitian yang sudah pernah dipublikasi, dimana penelitian-penelitian tersebut menggunakan based population maupun studi epidemiologi, sedangkan penelitian ini hanya mengambil data dari 2 laboratorium PA. Jika dilakukan penelitian lebih lanjut dengan populasi yang lebih luas mungkin akan mendapatkan hasil yang sama dengan penelitian-penelitian yang sudah ada.

Kepustakaan menyebutkan bahwa insiden keganasan meningkat terus sesuai dengan peningkatan usia dimana kasus keganasan sering ditemukan pada dekade ke 5 dan ke $6{ }^{2,6}$ Pernyataan ini tidak sesuai dengan hasil penelitian ini dimana pada tabel 3 terlihat bahwa distribusi dari jumlah penderita tumor kelenjar liur berdasarkan usia dan sifat tumor tidak merata. Bahkan pada kelompok usia 51 - 60 dan 61 - 70 penderita tumor jinak kelenjar liur lebih banyak daripada penderita tumor ganas kelenjar liur. Kepustakaan menyebut tumor kelenjar liur jarang pada anak-anak dan hasil penelitian ini membuktikan demikian. ${ }^{14}$ Pada kelompok usia $\leq 16$ tahun hanya ditemui 1 penderita tumor jinak kelenjar liur. Hal ini dikarenakan tumor butuh waktu $20-25$ tahun agar gejalanya diketahui.

Berdasarkan klasifikasi histopatologi, sebanyak 57 orang $(81,4 \%)$ menderita tumor jinak kelenjar liur sedangkan 13 orang $(18,6 \%)$ lainnya menderita keganasan dari tumor kelenjar liur. Dari 57 penderita tumor jinak kelenjar liur, jenis pleiomorphic adenoma mendominasi dengan jumlah sebanyak 40 penderita $(57,2 \%)$ dan di tempat kedua ada Whartin's tumor sebanyak 8 penderita $(11,45)$. Hal ini sesuai dengan apa yang kepustakaan katakan bahwa tumor kelenjar liur yang paling umum adalah Pleiomorphic adenoma yang merupakan tumor jinak dan tumor jinak kedua terbanyak adalah jenis Whartin's tumor. ${ }^{1-4,6,14}$

Pada tahun 2002, Vargas PA et al. ${ }^{12}$ telah melaporkan bahwa dari 124 kasus tumor kelenjar liur, sebanyak 99 kasus (80\%) adalah tumor jinak kelenjar liur dan sisanya, yaitu 25 kasus (20\%) merupakan kasus keganasan. Jenis Pleiomorphic adenoma mendominasi sebanyak 84 kasus (59\%) dan sebanyak 13 pasien (10,5\%) didiagnosis dengan Whartin's tumor.

Sedangkan di tahun 2005, Ito FA et al. ${ }^{11}$ melaporkan bahwa dari 496 kasus tumor kelenjar liur, sebanyak 335 kasus (67,5\%) adalah tumor jinak dan sisanya, yaitu 161 kasus (32,5\%) adalah kasus keganasan tumor kelenjar liur. Sebanyak 269 kasus (54,2\%) merupakan jenis Pleiomorphic adenoma dan pada urutan kedua tampak berbeda dengan hasil penelitan ini dan penelitian dari Vargas PA et al. ${ }^{12}$ Karena Ito FA et al. ${ }^{11}$ melaporkan setelah Pleiomorphic adenoma, jenis kedua terbanyak adalah mucoepidermoid carcinoma sebanyak 67 kasus (13,5\%) dan Whartin's tumordi tempat ketiga dengan $8,5 \%$ atau 42 kasus. Pinkston JA et al. ${ }^{13}$ menyampaikan pada tahun 1999 bahwa dari 248 kasus tumor kelenjar liur, didapati 84,3\% merupakan kasus jinak dari tumor kelenjar liur. Penelitian-penelitian ini menunjukan bahwa sebagian besar kasus tumor kelenjar liur adalah kasus jinak.

Dari penelitian ini ditemukan sebanyak 13 pasien (18,6\%) menderita keganasan kelenjar liur dengan angka terbanyak pada jenis mucoepidermoid carcinoma sebanyak 4 penderita (5,7\%) dan jenis adenocarcinoma yang juga sebanyak 4 penderita $(5,7 \%)$, kemudian diikuti jenis adenoid cystic carcinoma sebanyak 3 penderita (4,3\%). Jika diolah lebih lanjut, ternyata mucoepidermoid carcinoma menempati 30,8\% dari 13 kasus keganasan yang diperoleh sehingga menunjang apa yang disebutkan kepustakaan tentang mucoepidermoid carcinoma yang menempati $35 \%$ dari seluruh keganasan kelenjar liur. ${ }^{2-4}$ Berbeda dengan apa yang diperoleh Pinkston JA et al. ${ }^{13}$ yang menyatakan mucoepidermoid carcinoma menempati 51,3\% dari seluruh keganasan kelenjar liur. Begitu pula dengan Vargas PA et al. ${ }^{12}$ yang mengatakan bahwa mucoepidermoid carcinoma menempati 52\% dari seluruh tumor ganas kelenjar liur. Laporan dari Badan Registrasi Indonesia bahwa sepanjang tahun 2003 - 2007, di RS 
Kanker Darmais , ada total 82 kasus kanker kelenjar liur dengan jenis kanker terbanyak adalah mucoepidermoid carcinoma sebanyak 16 kasus. ${ }^{10}$ Meskipun berbeda secara kuantitatif maupun besar persentase, tetap dapat disimpulkan bahwa mucoepidermoid carcinoma merupakan jenis tumor ganas tersering di kelenjar liur.

Insiden tumor kelenjar liur terbanyak berasal dari kelenjar parotis (47,1\%), 27,1\% dari kelenjar submandibula, $12,9 \%$ berasal dari kelenjar liur minor baik itu palatum durum, palatum mole, bukal, dan lingual. Sedangkan sisanya sebesar 12,9\% keterangan lokasi di arsipnya tidak jelas seperti colli, rahang bawah, maupun tidak tercatat, sehingga peneliti mengelompokan sebagai lain-lain. Sedangkan kepustakaan menyebutkan dari seluruh insiden tumor kelenjar liur, diperkirakan $80 \%$ berasal dari kelenjar parotis, $10-15 \%$ dari kelenjar submandibula, sekitar 5-8\% dari kelenjar minor, dan $<1 \%$ berasal dari kelenjar sublingual. ${ }^{1-3}$ Selama penelitian ini penulis tidak menemukan lokasi sublingual yang tercantum jelas di arsip.Adapun kelenjar submandibula menjadi lokasi tersering dari keganasan kelenjar liur, hal ini terlihat dari 13 kasus keganasan, 6 diantarannya (46,2\%) berasal dari kelenjar submandibula.

\section{SIMPULAN}

Dalam periode Juli 2010 - Juli 2013 di RSUP Prof. Dr. R.D. Kandou ditemukan jumlah penderita tumor kelenjar liur sebanyak 70 penderita dengan jenis kelamin terbanyak adalah perempuan dan kelompok usia tersering yaitu 17 - 30 tahun. Berdasarkan sifat tumor, tumor jinak kelenjar liur $(81,4 \%)$ lebih banyak daripada keganasannya (18,6\%). Tumor kelenjar liur yang paling umum adalah pleiomorphic adenoma sebanyak 40 penderita (57,2\%) Tumor ganas tersering adalah jenis mucoepidermoid carcinoma dan adenocarcinoma yang sama-sama sebanyak 4 penderita (5,7\%). Lokasi tersering asal tumor adalah kelenjar parotis $(47,1 \%)$, dan lokasi tersering keganasan adalah kelenjar submandibula.

\section{SARAN}

Perlu dilakukan penelitian tentang gambaran histopatologi tumor kelenjar liur dengan populasi yang lebih luas lagi untuk memperbanyak data tentang tumor kelenjar liur di Indonesia.

\section{DAFTAR PUSTAKA}

1. Kurnia A. Kanker kepala leher dan rekonstruksi. Jakarta: Balai Penerbit FKUI; 2008. h. 73-94.

2. Manuaba TW. Panduan penatalaksanaan kanker solid PERABOI 2010. Sagung Seto; 2010. h. 74-97.

3. Futran ND, Parvathaneni U, Martins RG, Laramore GE. Malignant salivary gland tumors. Dalam: Harrison LB, Sessions RB, Ki-Hong W, editor. Head and neck cancer: a multidisciplinary approach. Ed. 3. Philadelphia: Lippincott Williams \& Wilkins; 2009. h. 589-610.

4. Speight PM, Barrett AW. Salivary glands and saliva: salivary gland tumors. Oral diseases. 2002;8:229-40.

5. Barnes L, Eveson JW, Reichart P, et al. World health organization classification of tumours: pathology and genetics of head and neck tumours. Lyon: IARCPress; 2005. h. 209-81.

6. Chahin F. Salivary gland tumors, major, benign. Medscape. 1 Desember 2011. [diakses 30 Agustus 2013]. Available from:http://emedicine.medscape.com/article/ 194357-overview\#a04

7. Million RR, Cassisi NJ, Mancuso AA. Major salivary gland tumors. Management of head and neck cancer: A multidisclipinary approach. Edisi ke-2. Philadelphia: J.B. Lippincott Company; 1994. h. 711-35.

8. Wiliyanto O. Insidensi Kanker Kepala Leher Berdasarkan Diagnosis Patologi Anatomi di RS Dr. Kariadi Semarang Periode 1 Januari 2001 - 31 Desember 2005 [Skripsi]. FK Undip; 2006.

9. Lisnawati, Stephanie M, Hamdani C. Diagnostic accuracy and cytomporphology analysis of fine needle aspiration of salivary gland. Med J Indones. 2012;21:92-6. 
10. Sinuraya ES. Registrasi Kanker Berbasis Rumah Sakit di Rumah Sakit Kanker Dharmais 2003-2007. Jakarta, Laporan Kerja Subbagian Registrasi Kanker Bagian Penelitian dan Pengembangan Rumah Sakit Kanker Dharmais Pusat Kanker Nasional Departemen Kesehatan Republik Indonesia. 2012: 27, 31, 33, 35, 37, 38 [diakses 10 September 2013]. Available from: http://www.scribd.com/doc/111890699/Regi strasi-Kanker-Berbasis-Rumah-Sakit-DiRSKD-2003-2007

11. Ito FA, Ito K, Vargas PA, et al. Salivary gland tumors in a Brazilian population: a retrospective study of 496 cases. Int J Oral Maxillofac Implants. 2005;34:533-36.
12. Vargas PA, Gerhard R, Filho VJFA, et al. Salivary gland tumors in a Brazilian population: a retrospective study of 124 cases. Rev Hosp Clin Fac Med S Paulo 57. 2002;6:271-6.

13. Pinkston JA, Cole $P$. Incidens rates of salivary glands tumors: Result from a population-based study. Otolaryngol Head Neck Surg. 1999;120:834-40.

14. Lee SC. Salivary gland neoplasms. Medscape. 8 Maret 2013. [diakses 30 Agustus 2013]. Available from : http://emedicine.medscape.com/article/8523 73-overview 